\title{
Innovative development of the building complex on the basis of environmental and energy- efficient technologies
}

\author{
Ekaterina E. Kireeva ${ }^{1, *}$, Natalya N. Belanova ${ }^{1}$, Anna D. Kornilova ${ }^{1}$, Ekaterina K. \\ Chirkunova $^{1}$ \\ ${ }^{1}$ Samara State Technical University, 194, Molodogvardeyskaya str, Samara, 443001, Russia
}

\begin{abstract}
The objective of the current study was to determine the priorities of innovative development of the building complex on the basis of the analysis of the environmental and energy-efficient technologies that were applied. Analysis of energy efficiency and environmental technologies in the construction industry showed that residential housing consumes $23 \%$ of the total primary energy supply in Russia. The construction sector is responsible for $30 \%$ of $\mathrm{CO} 2$ emissions into the atmosphere. Russia annually spends approximately 170 million tons of fuel equivalents for heating, ventilation and air conditioning of residential housing. Comparing Russia with the countries of similar climatic conditions it should be noted that energy consumption value in Russia is significantly higher (the excess ranges from 24 to $47 \%$ depending upon the building). Having analyzed the housing the authors offer the ways of building complex innovative development that mean the following: reindustrialization of material and technical resources of construction companies and the introduction of managerial innovations; the development and application of new high-tech building structures, products and materials that are to ensure the economic and environmental efficiency of buildings' construction and operation.
\end{abstract}

\section{Introduction}

Nowadays the building complex plays an important role in providing natural conditions that are necessary for supporting normal human life.

The construction industry of the national economy include building, reconstruction and technical retooling of industrial and nonindustrial objects, thus providing not only production activity but satisfying people's material and cultural needs.

N.A. Asaul, B.B. Khrustalev, P.G Grabovy [1-3] and others made a great contribution to the study of modernization and innovative development of the building complex searching for the best management solutions in the investment and construction.

Active research in the field of designing energy-effective buildings was carried out by V.N. Bogoslovsky, I.D. Boguslavsky, I.N. Butovskoy, V.G. Gagarin, A.A. Grishan and

*Corresponding author: kireevaee@mail.ru 
others [4-9].The problems of environmental safety were paid attention to in the works of A.A. Gusakov, M.Y. Slesarev, V.I. Telychenko, A.N. Dmitriyev [10-14].These issues are discussed in the scientific research works of foreign authors [15-18].

The objective of the current study was to determine the priorities of innovative development of the building complex on the basis of the analysis of the environmental and energy-efficient technologies that were applied.

\section{Methods}

The methodological basis of the study were the fundamental provisions of the economic theory, scientific works by Russian and foreign scientists in the field of construction economics, the results of various applied studies in applying ecological and energy-efficient technologies in the building complex.

To date, certain methods and approaches to the assessment of regularities and trends of the innovative development of the building complex have formed in the economics. However, none of them can be considered universal for the study of this process.

As a methodological framework, we used in the course of our study the dialectic, systemic-functional, economic-statistical and formally logical methods.

\section{Results}

Green retrofit of housing is caused by the growth of tariffs for energy resources. It is unlikely that the global economic crisis, the depletion of the world's oil, gas and coal deposits will encourage Russians to invest in sustainable buildings. But green retrofit of housing may become quite profitable [19]. It makes it possible not only save on electricity, hot water and heating, but also earn money by selling the excess biofuel, compost and agricultural products.

Nowadays the environmental factors of residential housing are more expensive than traditional residential buildings. But the Western experience proved that refuse from largescale engineering networks makes massive construction of eco-homes much cheaper.

This is due to the fact that during the winter period heating system accidents occur, people are deprived of heat and it costs a lot to repair the worn-out pipes in the frozen ground. The potential eco-friendly management can be provided not only at the expense of introducing environmental engineering and technology but also through greening methods and management tools. For this purpose it is necessary to develop management aimed at organizing and applying the ecological production and the ecological culture of human life. In our view in construction eco-friendly management should be based on the following approaches:

1. An ecosystem management approach (biosphere reconcilability).

Residential housing consumes $23 \%$ of the total primary energy supply in Russia. The construction sector is responsible for $30 \%$ of $\mathrm{CO} 2$ emissions into the atmosphere. Just for heating, ventilation and air-conditioning of residential buildings Russia annually spends approximately 170 million tons of fuel equivalents. In comparison with the countries with similar climates energy consumption value in Russia is significantly higher (the excess ranges from 24 to $47 \%$ depending upon the building. Special feature of Russia is district heating that dominates and comprises $56 \%$ in heating and $69 \%$ in hot water supply, whereas in Europe it is only $12 \%$.

2. Management focused on environmental life cycle of construction products:

-extraction and processing of natural raw materials for the production of building materials, building items and structures; 
-production of building materials, building items and structures;

-design and construction of facilities;

-operation of construction products;

-elimination and recycling of building materials and structures under reconstruction and demolition of construction objects.

More than 3 billion tons of raw materials such as sand, clay, gypsum, limestone, granite, basalt and many other sedimentary and igneous rocks are extracted and processed annually that causes great environmental damage by polluting the air and the ground [10].

3. Creating socio-environmental responsibility of the construction business. Socioenvironmental responsibility of construction business is a voluntary contribution of investment-construction sector. The activity is aimed at manufacturing construction products in the way that meets the requirements of environmental safety and sustainable use of natural resources given in regulatory documents and the healthy environment for human life and society development.

4. Reconciling the authority, business, and society interests while reasoning and making construction and investment decisions.

5. Greening the demand for construction products. The market demand for environment friendly construction products is the most important condition of greening. Consumers should be ready to pay for eco-friendly materials, resource-and energy-saving engineering.

One of the major problems of providing the sustainable development is to optimize the consumption of non-renewable resources.

This problem can be partly solved through the use of energy efficient solutions in the construction industry. The greatest heat loss in apartment houses falls on walls as most windows with wooden frames have been replaced with plastic ones and now meet modern building codes. However, heat transmission resistance differs according to the type of apartment houses (see table 1) [20].

Table 1. Comparison of different types of apartment houses according to heat transmission resistance of enclosures

\begin{tabular}{|c|c|c|c|}
\hline No. & Type of apartment house & $\begin{array}{c}\text { Heat transmission } \\
\text { resistance R, w/m2 * } \mathrm{C}^{0}\end{array}$ & $\begin{array}{c}\text { Heat loss } \\
\text { (compared to } \\
\text { modern houses), } \%\end{array}$ \\
\hline 1 & $\begin{array}{c}\text { Apartment houses built in } 30-50 \text {-ies. } \\
\text { (brick walls } \mathrm{t}=640 \mathrm{~mm} \text { ) }\end{array}$ & 1.14 & 66.86 \\
\hline 2 & $\begin{array}{c}\text { Apartment houses built in } 60-70 \text {-ies. } \\
\text { (ceramsite concrete panel } \mathrm{t}=400 \mathrm{~mm} \text { ) }\end{array}$ & 0.46 & 86.63 \\
\hline 3 & $\begin{array}{c}\text { Apartment houses built in } 80-90 \text {-ies. } \\
\text { (multilayer haydite concrete slab with } \\
\text { the insulation layer of average } \\
\text { thickness) }\end{array}$ & 2.91 & 0.00 \\
\hline 4 & $\begin{array}{c}\text { Modern houses that correspond to } \\
\text { technical regulations of 2003 and later. }\end{array}$ & 3.44 & \\
\hline
\end{tabular}

Heat transmission resistance calculation was made without considering the freezing of interpanel joints. Thus, real heat loss of panel type houses built in 60-70-ies and 80-90-ies would be higher if major repair of interpanel joints wasn't made. The houses built in 60-70ies are heat loss leaders.

Modern houses correspond to energy efficiency class "C" and but proper use of such house is required for real energy saving. At that over $50 \%$ of residential apartment buildings have energy efficiency class lower than "D". This includes panel houses built in 
$60-70$-ies and 80-90-ies. Their operation is impossible without the introduction of energyefficient technologies.

The following works can be included in the list of energy efficient solutions: installation of communal meters, control and regulation units of resource consumption, replacement of incandescent light bulbs with energy efficient bulbs in the common areas, installation of equipment for automatic room lighting in the common areas, insulation of facades by filling interpanel and expansion joints. These measures will make it possible to provide current level of resource and energy consumption and minimize the technogenic impact on the environment. Taking energy-efficient measures in construction industry provides environmental, economic and social effects that contribute to sustainable development. However, both private and public investment is required for putting these ideas into effect.

\section{Discussion}

Traditionally construction industry takes one of the leading places in the economy of the region. It is designed to realize the reproduction of fixed assets, reconstruction, modernization and technical re-equipment of wealth production on the contemporary technical basis. The implementation of the energy-efficient solutions in the work of the building complex will improve the innovative potential of the region.

The main priorities of the innovation development of the building complex are:

-reindustrialization of material and technical resources of construction companies and the introduction of managerial innovations. The use of efficient technologies will increase labour productivity and provide high competitiveness of the construction products, building materials, building items and structures. The introduction of managerial innovations will reduce the administrative and transaction costs;

-development and introduction of new high-tech building structures, products and materials that are to ensure the economic and environmental efficiency in the construction and maintenance of buildings, as well as their durability and fire safety. For this purpose it is necessary to follow the principle of making efficient construction systems that should ensure the high efficiency of construction structures and low operating costs. The application of new technologies in the production of building materials will make it possible to realize the technological breakthrough in the construction work;

-improving the quality of construction projects to ensure high consumer characteristics (reliability, safety, comfort, energy efficiency, operational efficiency through the application of modern automation systems for the engineering systems of buildings, i.e. the implementation of the concept "Smart House" [21];

- the introduction and application of innovative intellectual life support systems based on energy-saving technological innovations (geo- and helio- heat supply systems, wind turbines, solar water heaters, etc.), energy efficient ventilation systems (recuperators, house and apartment heating systems) as well as the use of alternative energy sources [22];

Governmental support of energy efficient housing is the main stimulating tool worldwide. A lot of countries take Government measures to support this trend in construction, such as concessional lending for the reconstruction of public and private buildings related to the increase of energy saving and preferential taxation for constructing the buildings of durable structures since much energy is consumed for the production of building materials [23].

New rules and regulations in the legislation framework should contribute to the development of "green" construction in Russia. Thus, state standards of "green" construction are being developed. Putting into effect these standards is one of the key challenges in implementing energy efficient construction methodologies. 


\section{Conclusions}

On the basis of the carried out research the following conclusions can be made:

1. For the innovative development of the building complex it is necessary to put into effect all of the above mentioned priorities, refine the legislative framework related to "green" construction and increase public support of construction companies that realize the projects of this kind.

2. One of the main challenges of sustainable development is the optimization of nonrenewable resource consumption. This problem can be partly solved by taking such energy efficient measures as the installation of communal meters, control and regulation units of resource consumption, replacement of incandescent light bulbs with energy efficient bulbs in the common areas, installation of equipment for automatic room lighting in the common areas, insulation of facades by filling interpanel and expansion joints.

3. The use of energy-efficient solutions in the building complex provides environmental, economic and social effects that contribute to sustainable development.

\section{References}

1. N.A. Asaul, A.V. Lobanov, Economic revival in Russia, 4, 17-24 (2009)

2. Y.S. Artamonova, B.B. Khrustalev, Actual problems of investment and building complex (Penza, 2014)

3. P.G. Grabovy, M.A. Lunyakov, Real Estate: economy and management, 1, 16-19 (2015)

4. V.G. Gagarin, V.V. Kozlov, Vestnik MGSU, 7, 59-66 (2011)

5. V.G. Gagarin, Ch. Chzhou, Housing Construction, 7, 18-22 (2015)

6. A.A. Grishan, Industrial Power Engineering, 7, 2-7 (2014)

7. A.S. Vilkova, K.A. Petul'ko, Energy saving technologies in construction, 8, 1268-1271 (2016)

8. L.A. Golovanova, E.D. Blum, Energy efficient construction design and technology, Scientific Notes of PNU, 4, 71-77 (2014)

9. M.Y. Onishchenko, N.I. Borisova, A.V. Borisov, Economics and Management of Innovative Technologies, 3 (2016)

10. G.A. Avalbaev, V.B. Ergashev, S.Y. Bobomuratova, S.Sagdullaeva, Young Scientist, 11, 564-566 (2016)

11. M.Y. Slesarev, Formation of ecological savety systems in construction (Moscow, 2012)

12. V.I. Telychenko, M.Y. Slesarev, Ecology of Urban Areas, 1, 13-17 (2013)

13. A.A. Gusakov, Building Materials, Equipment, Technologies of XXI Century, 5, 265267 (2004)

14. B.N. Porfir'ev, A.N. Dmitriev, Standards and Quality, 8, 16-21 (2016)

15. M.T. March, Architecture billings skyrocket to highest level of 2016 (2017)

16. C. Moreno, New Technology in the Construction Industry: The 10 Best Innovations of 2014 (2015)

17. O. Hägerstedt, J. Arfvidsson, Comparison of field measurements and Calculations of relative humidity and Temperature in Wood Framed Walls, Thermophysics: Conference proceedings (2010)

18. K. Sandberg, A. Pousette, S. Dahlquist, Wireless in situ measurements of moisture content and temperature in timber constructions (Porto, Portugal, 2011)

19. A.D. Kornilova, Science and Education: the new time, 2 (13), 50-54 (2016)

20. E.E. Kireeva, M. Kiy, Economic aspects of building complex management under modern conditions: int. scientific practical conf., 76-81 (Samara SUACE, 2016) 
21. E.K. Chirkunova, Economic aspects of building complex management under modern conditions: int. scientific practical conf., 113-117 (Samara SUACE, 2014)

22. M.I. Bal'zannikov, S.V. Evdokimov, N.V. Shekhova, Economy and property management, 1, 68-72 (2015)

23. N.N. Belanova, Economic aspects of building complex management under modern conditions: int. scientific practical conf., 166-170 (Samara SUACE, 2016) 